\begin{tabular}{lc}
\hline JOURNAL OF SCIENTIFIC PERSPECTIVES \\
RATING \\
E-ISSN: 2587-3008 \\
Attpril//ratingacademy.com.tr/journals/index.php/jsp/ 2018, Vol:2, Issue: 2 \\
\hline
\end{tabular}

\title{
DETERMINATION OF THE RELATIONSHIP AMONG RAW COW MILK COMPOSITION AND SOMATIC CELL COUNT OBTAIN FROM MILK COLLECTION CENTRES
}

\author{
Assist. Prof. Dr. Ayşe Gülin ESER* \\ Canakkale Onsekiz Mart University, Biga Vocatonal College, Canakkale, Turkey, E-mail: \\ gsezen@comu.edu.tr \\ Prof. Dr.Galin Y. IVANOV \\ University of Food Technologies, Department of Food Preservation and Refrigeration, Plovdiv, \\ Bulgaria

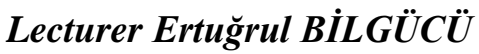 \\ Canakkale Onsekiz Mart University, Biga Vocatonal College, Canakkale, Turkey

\begin{tabular}{|c|c|}
\hline ARTICLE INFO & ABSTRACT \\
\hline $\begin{array}{l}\text { Article History: } \\
\text { Received: } 19 \text { March } 2018 \\
\text { Accepted: } 02 \text { April } 2018\end{array}$ & \multirow{3}{*}{$\begin{array}{l}\text { This study investigates protein, amount offat, lactose, dry matter, point of freezing } \\
\text { and number of somatic cells (SCC) as well as the relationship among these } \\
\text { mentioned components of milk collected from milk collection tanks from three } \\
\text { different collection centers in Biga Town in Canakkale Province by using } 825 \text { raw } \\
\text { cow milk sample. Mastitis is a high cost sickness in dairy cattle production } \\
\text { industry and number of somatic cells (SCC) in the milk is an indicator of the } \\
\text { problem. SCC also cause loss in the productivity of raw milk and increase the } \\
\text { production costs of raw milk at the same time. Increased number of somatic cells } \\
\text { also affect content of lactose, protein and dry matter in the milk to a great extent. } \\
\text { This study aims to identify the relationship among SCC identified in raw cow milk } \\
\text { and dry matter, non-fat dry matter, fat, protein and lactose contents. }\end{array}$} \\
\hline $\begin{array}{l}\text { Keywords: Raw milk, } \\
\text { somatic cell, mastitis. }\end{array}$ & \\
\hline DOI: $10.26900 /$ jsp.2018.10 & \\
\hline
\end{tabular}

\section{INTRODUCTION}

Raw milk according to Turkish Food Codex Communiqué on Raw Milk and Heat Processed Drinking Milk is defined as the mammary gland secretion obtained by milking of one or more than one cow(s), Goat(s), sheep, buffalo(s); except the colostrum not having been heated above $40^{\circ} \mathrm{C}$ treated by any other process having equivalent effect (Anonymous, 2000). In addition to growth and development; it has many other important properties in its life cycle such as vitamins and minerals in protein and peptide constituents such as physiologically important immunoglobulins, enzymes, enzyme inhibitors, growth hormones and other hormones, growth factors and antimicrobial agents, as well as fatty acids (Besler and Ünal, 2006). In a healthy udder, the milk in the cistern is sterile. However, after reaching the canal, it is contaminated by microorganisms. These bacteria are also the bacteria that have previously reached the mammary gland or the streak canal. This is described by Kielwein (1985) as "contamination of raw milk during secretion." (Kielwein, 1985). Thus, the investigator reports that during secretion the first milk should be discarded without being used (Kurweil and Busse, 
1973; Tolle,1980; Alişarl1 et al.,2003). Nowadays, somatic cell count (SCC) is used as an important criterion in the determination of raw milk quality and udder health. The somatic cell is a name given to any cell of a living organism other than the reproductive cells. Somatic cells in milk consist of epithelial cells, large squamous cells, epithelial cell debris and non-nucleated cells, red blood cells (erythrocytes), plasma cells, colostrum corpuscles, and leukocytes. Somatic cells can be used as a criterion for diagnosing udder health and subclinical mastitis (Dohoo and Meek, 1982; Rice and Bodman, 1997; Manlongate et al., 1998). In the case of a bacterial infection in the udder or any trauma, the SCC in the milk begins to increase (Kaya et al., 2011).

Legally, in many countries, the SCC in the milk is used as an indicator to determine milk quality standards and determines the level of milk payments made to the producer. According to Turkish Food Codex Communiqué on Raw Milk and Heat Processed Drinking Milk (No: 2000/6) published the Ministry of Agriculture and Rural Affairs, the limitation to SCC found in milk has been determined as $\leq 500.000$ per milliliter (Anonymous, 2000). The European Union (EU), New Zealand, Australia and a few other countries have adopted a standard for maximum allowable cell counts in their Grade A type milk of 400,000 cell $/ \mathrm{ml}$. In Canada it is at 500,000 while it is 750,000 in the USA (Anonymous, 1998).

SCC in a healthy cow milk should be less than 200,000 cell/ml (Anonymous, 2006). However, SCC can be below $100,000 \mathrm{cell} / \mathrm{ml}$ in herds with good management or after the first lactation. SCC of more than 250,000 to 300,000 per $\mathrm{ml}$ is usually indicative of abnormal milk and a potential exposure of the udder to an infection (mastitis) leading to a decrease in milk yield and quality (Rice and Bodman, 1997; Atasever et al., 2010; Anonymous, 1998).

\section{MATERIAL AND METHODS}

In the research, 275 raw milk samples from the group I region, 275 samples from group II region and 275 samples from group III region, totaling 825 samples (sampling techniques of raw milk from cooling tanks were applied) were collected from milk collection centers from January to December 2015. Samples were taken to the laboratory in $100 \mathrm{ml}$ sterile cups preserving cold chain $\left(+4^{\circ} \mathrm{C}\right)$ and protein, fat ratio, lactose, dry matter, freezing point and somatic cell counts were examined on the same day. Flow cytometry (Bactocount IBCm, Bentley Instrument, USA) was used for somatic cell counts, protein, fat ratio, lactose, dry matter, freezing point (Anonim, 2013). Monthly average values obtained from weekly counts were used as data.

In the statistical study, statistical analyzes were performed after lactose, protein, total dry matter, freezing point, somatic cell counts of the milk samples were determined. The SPSS 19 package program was used to calculate the coefficient of correlations.

\section{RESULTS AND DISCUSSION}

The results obtained from the I. group are shown in Table 1. According to statistical analysis results (pearson correlation), a strong and statistically significant relationship of the fat ratio with protein $(\mathrm{r}=0,545 ; \mathrm{P}<0,001)$ and total dry matter rations $(\mathrm{r}=0.913 ; \mathrm{P}<0.001)$ determined. These results indicate that cow milks with high-fat milk content also have high protein and dry matter values. According to Table 1 , there is a weak but statistically significant relationship between fat content and freezing point of raw cow milk $(\mathrm{r}=0.192 ; \mathrm{P}<0.01)$.

While weak but statistically significant positive correlations were determined between lactose proportion and dry matter $(\mathrm{r}=0.227 ; \mathrm{P}<0001)$ and lactose proportion and freezing point $(\mathrm{r}=0,389 ; \mathrm{P}<0.001)$, weak but statistically significant negative correlation $(\mathrm{r}=-0.359 ; \mathrm{P}<0.001)$ was found between lactose proportion and SCC. This analysis suggests that animals with high lactose levels have low somatic cell counts. According to Table 1, there is a strong and 
statistically significant positive correlation between protein content and total dry matter. As a result of this analysis, it was determined that animals with high protein value also had high dry matter value. There is a weak but statistically significant positive relationship protein proportion with freezing point and SCC.

Table 1. Coefficient of correlations among proportions of fat, lactose, protein, total dry matter (TDM), freezing point (FP) and somatic cell count (SCC) in group 1.

\begin{tabular}{|c|c|c|c|c|c|c|}
\hline & Fat & Lactose & Protein & TDM & FP & SCC \\
\hline Fat & - & $-0,068^{\mathrm{NS}}$ & $0,545^{* * *}$ & $0,913^{* * *}$ & $0,192^{* *}$ & $0,094^{\mathrm{NS}}$ \\
\hline Lactose & & - & $0,064^{\mathrm{NS}}$ & $0,227^{* * *}$ & $0,389^{* * *}$ & $-0,359^{* * *}$ \\
\hline Protein & & & - & $0,758^{* * *}$ & $0,194^{* *}$ & $0,154^{*}$ \\
\hline TDM & & & & - & $0,301^{* * *}$ & $0,029^{\mathrm{NS}}$ \\
\hline FP & & & & & - & $-0,123^{\mathrm{NS}}$ \\
\hline
\end{tabular}

NS: $\mathrm{P}>0.05 ; * \mathrm{P}<0.05 ; * * \mathrm{P}<0.01 ; * * * \mathrm{P}<0.001$

The results obtained from group II region are provided in Table 2. According to Table 2 , there is a positive and statistically significant correlation of fat proportion with total dry matter ratio ( $\mathrm{r}=0.914 ; \mathrm{P}<0.001)$, freezing point $(\mathrm{r}=0.222 ; \mathrm{P}<0.001)$ and $\mathrm{SCC}(\mathrm{r}=0.144 ; \mathrm{P}<0.05)$. These results indicate that milk of cows with high values in terms of milk fat ratio have higher protein ratios, total dry matter ratios, freezing point and SCC. A strong positive correlation between protein ratio and total dry matter ratio $(\mathrm{r}=0.702 ; \mathrm{P}<0.001)$ was determined.

While lactose ratio had a positive correlation with lactose ratio and total dry matter ratio $(\mathrm{r}=0.286 ; \mathrm{P}<0.001)$ and freezing point $(\mathrm{r}=0.608 ; \mathrm{P}<0.001)$, a negative correlation between lactose ratio and SCC $(\mathrm{r}=-0.274 ; \mathrm{P}<0.001)$ was determined. This result indicates that as the lactose ratio in the milk increases, the SCC decreases.

It was observed that as the total dry matter ratio increased the freezing point also increased $(\mathrm{r}=0.364 ; \mathrm{P}<0.001)$. There is a weak but statistically significant negative correlation between the freezing point and $\mathrm{SCC}(\mathrm{r}=-0.128 ; \mathrm{P}<0.05)$.

Table 2. Coefficient of correlations among proportions of fat, lactose, protein, total dry matter (TDM), freezing point (FP) and somatic cell count (SCC) in group 2.

\begin{tabular}{|c|c|c|c|c|c|c|}
\hline & Fat & Lactose & Protein & TDM & FP & SCC \\
\hline Fat & - & $0,018^{\mathrm{NS}}$ & $0,511^{* * *}$ & $0,914^{* * *}$ & $0,222^{* *}$ & $0,144^{*}$ \\
\hline Lactose & & - & $-0,043^{\mathrm{NS}}$ & $0,286^{* * *}$ & $0,608^{* * *}$ & $-0,274^{* * *}$ \\
\hline Protein & & & - & $0,702^{* * *}$ & $0,049^{\mathrm{NS}}$ & $0,102^{\mathrm{NS}}$ \\
\hline TDM & & & & - & $0,364^{* * *}$ & $0,069^{\mathrm{NS}}$ \\
\hline FP & & & & & - & $-0,128^{*}$ \\
\hline
\end{tabular}

NS: $\mathrm{P}>0.05 ; * \mathrm{P}<0.05 ; * * \mathrm{P}<0.01 ; * * * \mathrm{P}<0.001$

The results obtained from III group region are provided in Table 3. According to Table 3; fat proportion had positive correlation with protein ratio $(\mathrm{r}=0.381 ; \mathrm{P}<0.001)$, total dry matter ratio $(\mathrm{r}=0.856 ; \mathrm{P}<0.001)$ and freezing point $(\mathrm{r}=0.152 ; \mathrm{P}<0.05)$, and a negative but statistically significant correlation between fat and lactose ratio $(\mathrm{r}=-0.184 ; \mathrm{P}<0.01)$. These results indicate that milk of cows with high values of milk fat ratio have higher protein ratios, total dry matter ratios and freezing point; while the lactose ratio is lower.

A positive correlation between protein ratio with total dry matter ratio $(\mathrm{r}=0.690$; $\mathrm{P}<0.001)$ and freezing point $(\mathrm{r}=0.182 ; \mathrm{P}<0.01)$ was determined. 
While there was a positive correlation between lactose ratio with total dry matter ratio $(\mathrm{r}=0.163 ; \mathrm{P}<0.01)$ and freezing point $(\mathrm{r}=0.438 ; \mathrm{P}<0.001)$, there was a negative correlation between lactose ratio and somatic cell count $(\mathrm{r}=-0.127 ; \mathrm{P}<0.05)$. This result indicates that as the lactose ratio in the milk increases, the total dry matter ratio and freezing point increase, while the number of somatic cells decreases.

It was observed that as the total dry matter ratio increased, the freezing point also increased $(\mathrm{r}=0.334 ; \mathrm{P}<0.001)$.

Tablo 3. Coefficient of correlations among proportions of fat, lactose, protein, total dry matter (TDM), freezing point (FP) and somatic cell count (SCC) in group 3.

\begin{tabular}{|c|c|c|c|c|c|c|}
\hline & Fat & Lactose & Protein & TDM & FP & SCC \\
\hline Fat & - & $-0,184 * *$ & $0,381^{* * *}$ & $0,856^{* * *}$ & $0,152^{*}$ & $0,112^{\mathrm{NS}}$ \\
\hline Lactose & & - & $-0,085^{\mathrm{NS}}$ & $0,163^{* *}$ & $0,438^{* * *}$ & $-0,127^{*}$ \\
\hline Protein & & & - & $0,690^{* * *}$ & $0,182^{* *}$ & $0,079^{\mathrm{NS}}$ \\
\hline TDM & & & & - & $0,334^{* * *}$ & $0,076^{\mathrm{NS}}$ \\
\hline FP & & & & & - & $-0,014^{\mathrm{NS}}$ \\
\hline
\end{tabular}

NS: $\mathrm{P}>0.05 ; * \mathrm{P}<0.05 ; * * \mathrm{P}<0.01 ; * * * \mathrm{P}<0.001,0$

In a study conducted to determine the relationship between SCC and milk composition, it was shown that as milk SCC increases, fat, protein, lactose and total dry matter content decreases. (Felix et al., 2005).

Ayaşan et al., (2011), reported that while low or high SCC in milk effect milk fat, milk lactose, nonfat dry matter and density statistically $(\mathrm{P}<0.05)$ the effects on milk protein, milk casein, dry matter, acidity, free fatty acid, citric acid and freezing point are insignificant.

Şahin and Kaşıçı (2014), investigated the two groups in their study and reported that in the group with high SCC, the relation between the number of somatic cells with protein $(\mathrm{r}=0.145)$, nonfat dry matter $(\mathrm{r}=-0.109)$ and lactose $(\mathrm{r}=-0.490)$ were significant $(\mathrm{P}<0.05)$, and the correlation of SCC with dry matter, nonfat dry matter, fat, protein and lactose contents were insignificant $(\mathrm{P}>0.05)$. They have specified that the relationship between fat content with protein and dry matter content were significant, while the relation between fat content and other milk components is insignificant $(\mathrm{P}>0.05)$. They have determined while the relation between milk protein ratio and somatic cell number in group I was negative and insignificant $(\mathrm{P}<0.05)$, it was positive and significant in the group II. In the same study, the correlation of nonfat dry matter content and SCC was not positive insignificant $(\mathrm{P}>0.05)$ in group I, whereas the relation in question was negative and significant $(\mathrm{P}<0.05)$ in group II In a study conducted by Reis et al., (2013) similar results were found.

Lactose, which affects the freezing point of milk, causes an increase in milk density (Demirci et al., 2010). Şahin and Kaşıkçı (2011) have determined milk lactose levels were 4.1\% in the group with high SCC and $4.7 \%$ in the group with low SCC $(\mathrm{P}<0.05)$. 
The relation between milk fat ratio and somatic cell counts in group II were negative and significant. In another study on Holstein cows, it was determined that the correlation between somatic cell count and fat content was $0.21(\mathrm{P}<0.05)$ (Konjačić et al., 2010).

Elevated levels of SCC in milk from cows with mastitis cause changes in milk enzymes, which causes the breakdown of proteins and fats. Plasmin, one of these enzymes, increases the breakdown of casein due to elevated SCC in milk. It, therefore, reduces the amount of casein in milk composition (Aytekin and Boztepe, 2014; Rajèeviè et al., 2003). In the study we have conducted, it was determined that the increase in the number of somatic cells in milk caused the lactose content to decrease. A similar result was obtained in studies conducted by Şahin and Kaşıkçı (2014). Yet in other similar studies, it has been reported that lactose content decreases with the increase of SCC and that this relation is significant (Reis et al., 2013; Cerón-Muñoz et al., 2002; Paura et al., 2002; Sawa and Piwezynski, 2002).

\section{CONCLUSION}

The quantity of milk is as important as the quality of milk. The most important criterion affecting the quality of milk is the SCC and the milk components. As SCC increases in the raw milk, milk components are also negatively affected. An emphasis on animal health and welfare in farms, good herd management and udder and equipment hygiene on a producer basis will prevent the increase of SCC, and as a result milk component will be affected positively, hence the amount of milk and healthy milk will increase. Therefore, as per the Turkish Food Codex Communiqué on Raw Milk and Heat Processed Drinking Milk (No: 2000/6) published the Ministry of Agriculture and Rural Affairs, the limitation on SCC found in milk has been determined as $\leq 500.000$ per milliliter (Anonymous, 2000).

Today, pollution of water resources as a result of anthropogenic activities presents a great danger. With industrialization and urbanization, many wetlands are polluted, and this pollution directly or indirectly threatens the health of people and other living organisms. As a result of the studies and the different test methods used, it is clear that water and sediment are contaminated with many genotoxic compounds and that these compounds cause mutagenic effects on different organisms. 


\section{REFERENCES}

ANONYMOUS 2000. Turkish Food Codex Communiqué on Raw Milk and Heat Processed Drinking Milk (Communique No: 2000/6) 14 February 2000 Number : 23964.

BESLER H, ÜNAL S., 2006. Ankara'da satılan sokak sütlerinin bazı vitaminler açısından değerlendirilmesi ve ev koşullarında uygulanan kaynatmanın süreye bağlı olarak vitaminlere olan etkisi. IV Uluslararası Beslenme ve Diyetetik Kongresi Bildiri Kitabı. s: 216, Ankara.

KIELWEIN, G., 1985. Mikrobielle Kontamination der Milch. In: Leitfaden der Milchkunde und Milchhygiene. Pareys Studientexte 11. ISBN3-489-68416-8. S: 51-71.

KURWEIL, R., BUSSE, M., 1973. Total count and microflora of freshly drawn milk. Milchwissenschaft, 28, 427.

TOLLE, A., 1980. The microflora of the udder. In Factors Influencing the Bacteriological Quality of Raw Milk. International Dairy Federation Bulletin, Document. 120, 4 p.

ALİSARLI, M., SOLMAZ, H., AKAYA, L., 2003. Süt ineklerinde meme başı derilerinin bazı mikroorganizmalar ve çiğ inek sütlerinin mikrobiyolojik kalite yönünden incelenmesi. Yüzüncü Y1l Universtiy Veterinary Journal, 14(1): 35-39.

DOHOO, I.R., MEEK, A.H., 1982. Somatic cell counts in Bovine Milk. Can Vet J. 23: 119125.

RICE, DN., BODMAN, G.R., 1997. The somatic cell count and milk quality. http://www.ianr.unl.edu/pubs/dairy/g 506.htm [Erişim: 05.2005].

MANLONGATE, N., YANG, T.J., HINCKLEY, L.S., BENDEL, RB., KRIDER, HM., 1998. Physiologic-chemoattractant-induced migration of polymorphonuclear leukocytes in milk. Clin. Diagn. Lab. Immunol. 5: 375-381.

KAYA, İ., UZMAY, C., AYYILDIZ, T., ÜNLÜ, H.B., 2011. Ege Universitesi Ziraat Fakültesi Menemen Araştırma ve Uygulama Çiftliğinde Yetiştirilen Siyah Alaca İneklerde Somatik Hücre Ölçümüne Dayalı Olarak Meme Sağlığının Durumu. Ege University Journal of Agricultural Faculty. 48 (3): 229-239.

ANONYMOUS 1998. Ingalls. W. 1998. Somatic Cells, Mastitis and Milk Quality. Ph.D West Agro, Inc., Kansas City, MO. http://www.moomilk.com/archive/u-health-20.htm [Erişim: 05.2005].

ANONYMOUS, 2006. Commission Regulation (EC) No: 1662/2006. Amending Regulation (EC) No 853/2004 of the Europen Parliament and of the Council Laying Down Specific Hygiene Rules for Food of Animal Origin.

ATASEVER, S., ERDEM, H., ALTOP, A., 2010. Relationships Between Milk Somatic Cell Count and pH in Dairy Cows. Journal of Animal and Veterinary Advences. 9(11): 15751577. 
ANONIM 2013. About Bentley Instruments. http://bentleyinstruments.com/about-us. [Erişim tarihi: 28.12.2013].

FÉLIX, B.V.F., JOSÉ, M.A., SOARES, N.E., NONATO, O.A., PEREIRA, O.J., SOARES, N.R.B., GARCIA, M.J.R., WERNER, T.L., 2005. Contagem celular somática: relação com a composição centesimal do leite e período do ano no Estado de Goiás. Ciência Rural, Santa Maria. 35 (4): 848-854.

AYAŞAN, T., HIZLI, H., YAZGAN, E., KARA, U., GÖK, K., 2011. Somatik Hücre Sayısının Süt Üre Nitrojen İle Süt Kompozisyonuna Olan Etkisi. Kafkas Univ Veterinary Journal. 17: 659-662.

ŞAHIN, A., KAŞIKÇI, M., 2014. Esmer İneklerde Somatik Hücre Sayısı ve Bazı Çiğ Süt Parametreleri Arasındaki İlişkilerin Belirlenmesi. Turkish Journal of Agriculture - Food Science and Technology 2(5): 220-223.

REIS, C.B.M., BARRERIO, J.G., MESTIERI, L., PORCIONATO, M.A.F., SANTES, M.V., 2013. Effect of somatic cell count and mastitis pathogens on milk composition in gry cows. Bmc Veterinary Research. 9(67): 2-7.

DEMİRCİ, M., ÖKSÜZ, Ö., ŞİMŞEK, O., KURULTAY, Ş., KIVANÇ, M., GÜNDÜZ, H.H., UÇAN, N., 2010. Süt ve Süt Ürünlerinin Kalite Kontrolü, Anadolu University Publication. 2064. 254s.

KONJAČIĆ, M., KELAVA, N., IVKIĆ, Z.., IVANKOVIĆ, A., PRPIĆ, Z., VNUČEC, I., RAMLJAK, J., MIJII, P., 2010. Non-nutritional factors of milk urea concentration in Holstein cows from large dairy farms in Croatia, Mljekarstvo 60(3): 166-174.

AYTEKİN, İ., BOZTEPE, S., 2014. Süt Sığırlarında Somatik Hücre Sayısı, Önemi ve Etki Eden Faktörler. Turkish Journal of Agriculture - Food Science and Technology 2(3): 112-121.

RAJĖEVIÈ, M., POTOÈNIK, K., LEVSTEK, J., 2003. Correlations Between Somatic Cells Count and Milk Composition with Regard to the Season, Agriculturae Conspectus Scientificus, 68: 221-226.

CERÓN-MUÑOZ, M., TONHATI, H., DUARTE, J., MUÑOZ-BERROCAL, M., JURADOGÁMEZ, H., 2002. Factor saffecting somatic cell counts and their relations with milk and milk constituent yield in buffaloes. Journal of Dairy Science, 85: 2885-2889.

PAURA, L., KAIRISHA, D., JONKUS, D., 2002. Repeatability of milk productivity traits. Veterinarija ir zootehnika,19: 90-93.

SAWA, A., PIWCZYNSKI, D., 2002. Somatic cell count and milk yield and composition in Black and White x Holstein-Friezian cows. Medycyna Weterynaryjna, 58: 636-640. 
ESER et al. / Determinatıon of the Relationship Among Raw Cow Milk Composition And Somailc Cell Count Obtain From Milk Collection Centres 